China Perspectives

2020-1 | 2020

Sights and Sounds of the Cold War in Socialist China and Beyond

\title{
Familiar Strangers: Images and Voices of Soviet Allies in Dubbed Films in 1950s China
}

$\mathrm{Nan} \mathrm{Hu}$

\section{OpenEdition}

\section{Journals}

Electronic version

URL: https://journals.openedition.org/chinaperspectives/9907

DOI: 10.4000/chinaperspectives.9907

ISSN: 1996-4617

Publisher

Centre d'étude français sur la Chine contemporaine

Printed version

Date of publication: 1 March 2020

Number of pages: 25-31

ISSN: 2070-3449

\section{Electronic reference}

Nan Hu, "Familiar Strangers: Images and Voices of Soviet Allies in Dubbed Films in 1950s China", China Perspectives [Online], 2020-1 | 2020, Online since 01 March 2021, connection on 02 July 2021. URL: http://journals.openedition.org/chinaperspectives/9907; DOI: https://doi.org/10.4000/ chinaperspectives.9907 


\title{
Familiar Strangers: Images and Voices of Soviet Allies in Dubbed Films in 1950s China
}

\author{
NAN HU
}

\begin{abstract}
After the establishment of the People's Republic of China (PRC), dubbed Soviet films became an important tool to promote the Sino-Soviet alliance among the Chinese people. This essay explores the representation of the Soviet allies through the dubbing of Soviet films in 1950s China, with a focus on not only the content of these voices, but also the techniques and aesthetics of voicing. It shows that although designed by the PRC to produce an image of the Soviets as relatable and familiar, these films also produced an image of strangers, which allowed alternative imaginations of the Soviet characters and the Sino-Soviet relationship. This paper argues for the ambiguity of the image of the "Soviet big brothers" in dubbed films in the 1950s, which disrupted the official imagination of the relationship between the Chinese and the world.
\end{abstract}

KEYWORDS: Film translation, Soviet films, dubbing, voice performance, domestication, foreignization.

\section{Introduction}

( n 29 December 1953, the newsroom of Popular Cinema (Dazhong dianying 大衆電影) in Beijing held a New Year gala for Chinese translators and dubbing artists of foreign films and their audience. Among the guests were dubbing artists Che Xuan 車軒, Wu Jing 吳靜, and Bai jingsheng 白景晟, who dubbed, respectively, for the characters of Yakov Sverdlov (in M. Itina and Sergei Yutkevich's Yakov Sverdlov, 1940, translated into Chinese in 1951), Zoya Kosmodemyanskaya (in Lev Arnshtam's 1944 film Zoya, translated in 1950), and Joseph Stalin (in Mikheil Chiaureli's Unforgettable Year 1919, 1951, translated in 1952). The audience applauded wildly and "connected the heroic figures with the dubbing artists right away": "It was the first time they met, but the audience was very familiar with their voices." Representatives from the audience claimed that the Soviet heroes' devotion to the Communist Revolution inspired them to work hard on their own revolutionary projects, and the Soviet brothers' welldeveloped techniques kindled their passion to "create and invent" for the construction of a new socialist China. For the audience, the dubbing actors' work was essential for their connection with the Soviet big brothers: "If they speak Russian, we could never understand them. We are so grateful to you for speaking the revolutionary mentors' words in Chinese (...)." The celebration did not end until midnight (Bu 1954: 24-5).

This meeting shows that on the one hand, dubbed Soviet films were highly influential cultural products in the 1950s, which, according to the Chinese Communist Party, allowed ordinary Chinese people to know, get close to, and be inspired by the image of their Soviet heroes. In the 1950s, the People's Republic of China dubbed more than 300 Soviet films into Chinese in order to "enhance [its] relationship with the Soviet people": to promote proSoviet Cold War foreign policy, to reinforce Sino-Soviet friendship among the people, and to cultivate a worldview of a shared destiny and common future within the Socialist camp (Zhang 1957: 116). These films covered a variety of genres, including historical epic, war film, comedy, biopic, children's film, etc., and most of them showed Soviet people's struggle against fascism and imperialism, heroes devoting their lives to socialist revolution and construction projects, and a tomorrow of modernisation and abundance promised by socialism. They fostered the feeling of internationalism by revealing to the Chinese that the Soviets shared the same "progressive values," experience of "revolutionary struggle," and a future of prosperity with them (Chen 2004: 89). On the other hand, this meeting also demonstrated that this friendship-building mission could not be accomplished without the dubbing actors' work. The words or lessons of the "Soviet big brothers" had to be mediated by the Chinese language and Chinese voices to be understood and accepted by the Chinese audience. This paper focuses on the translation and dubbing of Soviet filmic characters and asks: how did the government's goal of forging a sense of intimacy with the Soviets and the illusion of a homogeneous Socialist culture within the Eastern Bloc shape the practices of translators and dubbing actors? How in turn did these practices legitimise and negotiate with the idea of the Sino-Soviet alliance?

The use of dubbed Soviet films to cultivate pro-Soviet sentiment was part of the national campaign of Sino-Soviet friendship around 1949. On 30 June 1949, on the eve of the establishment of the PRC, Mao Zedong announced the "Leaning to One Side" (yibiandao 一邊倒) policy, signifying clearly that China was taking the side of the Soviet Union in the Cold War. However, when this foreign policy was put into effect, government officials soon realised that the idea of a Sino-Soviet alliance was not supported by ordinary Chinese people. Reports show that around 1949, anti-Soviet sentiment was not uncommon among Chinese citizens. Traumatised by the long history of Russian invasion of China, many Chinese considered Soviets enemies or 
strangers rather than friends. ${ }^{1}$ Thus, the government saw an urgent need to cultivate a sense of closeness and friendship towards the Soviet people so as to support the government's pro-Soviet stance.

Literature on the Sino-Soviet relationship has long concentrated on political, diplomatic, military, and economic cooperation and conflicts (see, for example, Westad 1998; Lukin 2003; Heinzig 2004; Lüthi 2008; Radchenko 2009). These works, though telling stories about leaders and high-ranking officials in policymaking on the national level, rarely address the lower-level and grassroots dimensions of this relationship, such as the propaganda projects that connected the policies to the ordinary people, with little attention paid to cultural exchanges between the two socialist superpowers. After the millennium, more scholars started to focus on the cultural aspects of Sino-Soviet interactions (See Bernstein and Li 2009; Yu 2015; Volland 2017; Li 2018). Their works highlight grassroots society's role in the international relationship, take cultural exchanges as a crucial dimension of the Sino-Soviet alliance, and challenge the common perception that the Mao era was culturally isolated from the world. Among the Soviet cultural products introduced into China were dubbed Soviet films, which, while playing a significant part in cultural diplomacy and in shaping Chinese people's reception of their Soviet big brothers, still remain understudied.? Engaging with the few scholars who have touched upon this topic, I explore how the government used dubbed Soviet films to reach and influence the Chinese masses. I present these films as an important part of the CCP's project of winning Chinese "hearts and minds" for the Soviet allies and highlight the complexities within this project.

This paper also brings a new emphasis on the practices and politics of translating and dubbing. Recently, scholars have begun to pay attention to the importation, exhibition, and reception of foreign films in the PRC (Chen 2004; Huang 2013; Chen 2014; Du 2018). However, these studies largely ignore the nuanced translating and dubbing practices, as well as the Chinese filmmakers' agency in speaking for the foreign other. ${ }^{3}$ My study will look at these translating and dubbing processes, and present the heteroglossia within them, with a focus on the content of the dialogue, as well as the techniques, aesthetics, and politics of voicing. I adopt a broad definition of translation, which includes communication of meaning not only in written texts but also in verbal forms, and I argue that dubbing is essentially one major form of translation. To make the discussion clearer, I use "translation/translating" and "dub/dubbing" to specify the procedures of dialogue translation and voice performance during the process of making dubbed films. I borrow theoretical tools from both Translation Studies and Cinema Sound Studies to discuss two major questions: did translating and dubbing domesticise or foreignize the image of the Soviets? What impact did the phenomenon of "Soviet characters speaking Chinese" have on Chinese people's perception of the Soviets?

Using a wide range of materials including contemporary newspapers, film journals, government archives, autobiographies, oral histories, and interviews with translators/dubbing actors/spectators, and listening to the dubbing voices closely, I explore how the official rhetoric of Sino-Soviet friendship shaped Chinese filmmakers' translating and dubbing practices, and how the dubbed films contributed to, challenged, or deconstructed their own mission. I show that the dubbed Soviet films as well as dubbing practices were coded to support and cultivate Sino-Soviet friendship among the Chinese audience during the 1950s. Although designed by the PRC to produce an image of relatable and familiar foreigners as friends and comrades, these films also produced an image of strangers, which allowed an alternative imagination of the Soviet people as foreign among the Chinese audience. Overall, this paper argues for treating the image of the "Soviet big brothers" as ambiguous in dubbed films in the 1950s - an image that disrupted the official rhetoric of the Sino-Soviet friendship, and thus of China's relationship with the world.

\section{The rise of dubbing}

To delineate the rise of dubbed Soviet films and its importance to the Cold War propaganda of the Sino-Soviet alliance in the PRC, a brief prehistory of dubbing, or how the Chinese watched foreign films and especially Soviet films before 1949, is helpful. When film was first introduced into China at the end of the nineteenth century, Chinese people watched these "Western shadow plays" with the help of live interpreters and playbooks. As early as the 1920s, film companies started to experiment with showing foreign films with Chinese subtitles, which became a major approach of film translation through the 1930s. Later on, Chinese theatres introduced simultaneous interpretation into the audience's experience of watching foreign sound films - with a set of earphones called yiyifeng 譯意風, the audience listened to the narrated dialogues and storyline in Chinese while watching the films. Dubbing practices only appeared in the latter half of the 1940s in Shanghai, when Richard Thorpe's 1942 film Tarzan's New York Adventure was released in 1946 and Mario Camerini's 1940 drama A Romantic Adventure was exhibited in 1947. These films became forerunners for the PRC's dubbed foreign films, which started in 1949 with the Soviet classic Private Alexander Matrosov (1947) (Jin 2018: 197-8; Du 2018: 10-5).

The above narrative, focusing on Hollywood and other Western cinema shown for entertainment in big cities such as Shanghai, by no means covers the whole story of the screening of foreign films in Republican China. In fact, Soviet films had been shown in China since the 1920s, and the history of showing and translating these films before 1949 is of greater interest to my study here. The first exhibitions of Soviet films - a series of documentaries on Lenin's funeral - took place in 1924 in Shanghai and Tianjin (Cheng 1957: 77). During WWII, more Soviet films, including Lenin in October (1937) and Chapaev (1934), were screened in Yan'an. These films were accompanied by a simultaneous translator, who usually had studied in the Soviet Union (Shi 2015: 108). Not until 1946, when the Soviet Union established the delegation bureau of Sovexportfilm in Harbin, were Soviet films shown in China on a large scale. Most of the Soviet films shown by the Sovexportfilm in China were subtitled, and by 1948, the Sovexportfilm had shown several hundred Soviet films in this way in Northeastern China. Around 1948, Sovexportfilm also produced dubbed films: the first dubbed Soviet films were Zoya and Symphony of Life (1948), which were dubbed by Chinese students in Moscow "with a funny mixture of dialects from throughout China" (Meng 2003).

With the establishment of the PRC, for the first time in Chinese history, dubbing became the prevailing form of film translation. To produce dubbed films, the new regime built a series of translation and dubbing institutions, including the Dubbing Office of the Northeast Film Studio (Dongbei dianying zhipianchang fanbanzu 東北電影製片廠翻版組) and the Shanghai Film

\footnotetext{
1. For a more detailed study of the Chinese perception of the Soviets around 1949, see Hess (2007).

2. An exception is Tina Mai Chen's paper on Soviet films' circulation and reception in China, which is the first to discuss the role of these films in Maoist China.

3. In one chapter of her dissertation, Weijia Du discusses the impact of dubbing as opposed to subtitling on Chinese audiences from 1949 to 1994 . Her work reveals the general nature of dubbing in the PRC, but there is still the need for a closer look at the first days of dubbing in China - how dubbing practices were shaped by the historical context and how they influenced the audience's perception of the more specific political messages (Du 2018: 84-112).
} 
Dubbing Studio (Shanghai dianying yizhipian chang 上海電影譯製片廠). These studios recruited and trained teams of dubbing actors and actresses who could voice all kinds of characters in foreign films, and they primarily translated and dubbed films from the Soviet Union, at least during the early days. For the first three years, almost all the films these studios dubbed were from the Soviet Union. And for the entire 1950s, dubbed Soviet films made up more than half of their total production.

Why dubbing? What made dubbing a good choice for the PRC when it decided to introduce Soviet films to the Chinese audience on a large scale? Here I associate the rise of dubbing as the prevailing method of film translation with the PRC's foreign policy agenda towards the Sino-Soviet alliance. First, dubbing Soviet films allowed them to be understandable and approachable to the broadest possible Chinese audience, making dubbing the most logical choice for film translation. Filmmakers at the Northeast Studio claimed that before 1949, with the help of subtitles, playbooks, and interpreters, people in Northeast China could generally grasp the story of Soviet films, but "still felt difficulties" in understanding the meaning of the films (Liu and Meng 1952: 17). If we further take into consideration the low literacy rate in China in 1949, it is clear that the first and foremost reason for the CCP's choice of dubbing was that it allowed most Chinese to understand the films, which was crucial for any kind of further understanding or imagination of the friendship between the Chinese and the Soviets.

Second, compared to the subtitled Soviet films shown in China during the Republican era, dubbing guaranteed the accuracy and authority of the Soviet lesson to the Chinese. As Meng Guangjun 孟廣鈞, a translator at the Sovexportfilm and then the Northeast Studio, recalls, the early subtitles were crude. They were printed on a strip of film and projected on a separated screen below the regular screen; the subtitle image was divided into 4 frames, each of which contained 18 Chinese characters; a subtitle projectionist would manually change the subtitles projected. The translations were far from accurate, presumably because of the word limit, and they only served to convey the general idea of the dialogue (Meng 2003; Wang 2014: Kindle Locations 374-6). This flawed form of film translation did not meet the CCP's expectation for the translation of Soviet films, which were hailed by Liu Shaoqi 劉少奇, the Vice Chairman of the Central Covernment, as an expressway to "knowing and learning from the Soviets," and a tool for "enhancing the Sino-Soviet friendship" (Committee of Art in Film Bureau of the Ministry of Culture 1950: 9). In contrast, with the foreign characters speaking Chinese, dubbing promised a more accurate understanding of the Soviet characters. If we consider the hierarchy within the friendship - the Soviet Union being the teacher and the "big brother" - it is not hard to imagine that the PRC would welcome dubbing, which not only delivered the words of the Soviets with more accuracy but further enhanced the audience's understanding of the Soviet characters.

Third, dubbing facilitated Chinese audience's identification with the Soviet characters by allowing the viewer/listener to imitate and repeat the speech of the Soviet characters. A scene described by Liu Zhiguang 劉志廣, a streetcar mechanic from Beijing, is a good example. According to Liu, the dubbed Soviet films, especially Zoya, How the Steel Was Tempered (1942), and Private Alexander Matrosov, deeply impressed him and other workers, and he oftentimes heard his colleagues at work reciting Pavel Korchagin's famous line, "Man's dearest possession is life, and it is given to him to live but once..." (Bu 1954: 25). Liu's example shows a unique way of perceiving Soviet films in the 1950s, which included not only listening to the lines of the Soviet characters, but also remembering, repeating, and imitating them. On the one hand, the process of reciting changes the workers' relationship with revolutionary voices: the young workers listened to and remembered the voices of the Soviet big brothers, and further became voicers of the revolutionary messages themselves. They no longer passively listened to the voices but internalised and repeated them: as soon as they started to recite these words, they became a supporter and participant in the revolution. On the other hand, this process of reciting also changed the workers' relationship with the Soviet heroes on the screen. By chanting the same words as Pavel, or even imitating the emotions and tones of the character, the young workers in Beijing stood with the Soviet hero and joined the shared mission of fighting for the "finest cause in all the world - (...) the liberation of mankind." The dubbing performance made the lines recitable and imitable to a mass audience, changed the audience's way of interacting with the film, and encouraged the workers' transnational identification.

\section{"Now they are not only understandable, but also feel extremely intimate."}

As I have shown, the PRC's Cold War foreign policy of "leaning to one side" motivated not only the film translation project but also the choice of dubbing as the major method of film translation. This mission of cultivating transnational identification was not limited to the choice of dubbing or the organisation of dubbing institutions, but permeated the theories and methods of translating and dubbing practices. Turning to the filmmakers' practices of translating and dubbing for these Soviet films, I demonstrate in this section how the CCP expected the dubbed Soviet films, with their domesticated words, voices, and emotions, to produce the image of an understandable Soviet ally for the Chinese mass audience so as to facilitate transnational identification. I also reflect on this expectation with a brief view of theories on dubbing.

In the CCP's expectations for dubbed foreign films, domestication of the image of the foreigners was a major concern. As early as 1950, the central propagandists from the Committee of Art in the Film Bureau of the Ministry of Culture published their review of the film-dubbing project, in which they highlighted "Sinicization of translated films" as the first major issue to tackle. "The translated Soviet films are for the Chinese audience," the committee claimed, "so they should be Sinicized to a certain extent - although we also need to consider the original flavour" (Committee of Art in Film Bureau of the Ministry of Culture 1950: 9). This review highlights the strategy of domestication in making dubbed Soviet films in socialist China and its significance in constructing transnational identification.

First and foremost, officials in the Ministry of Culture believed that the medium of dubbed cinema encouraged the Chinese audience to feel close and intimate with the Soviet characters as well as the Soviet world depicted in the films because the Soviets speak Chinese: "In the past, the audience could not understand many of the Soviet films," the report goes; "now they not only understand, but also feel extremely intimate" (Committee of Art in Film Bureau of the Ministry of Culture 1950: 9). Because the Soviet allies spoke the target language on screen, which fundamentally domesticised the foreign film, the Chinese audience, according to the central propagandists' design, felt close to Soviet characters and identified them as their "big brothers."

\footnotetext{
4. The Dubbing Office of the Northeast Film Studio was built in 1949, as an affiliated office of the Northeast Film Studio. The Northeast Film Studio was renamed the Changchun Film Studio in 1955. Similarly, the Shanghai Film Dubbing Studio was first established as a translation group in the Shanghai Film Studio, which was created on 16 November 1949. In 1957, the group became independent from the Shanghai Film Studio and was named the Shanghai Film Dubbing Studio, showing the rising importance of dubbed films in Chinese cinematic industry.
} 
The process of dialogue translation also shortened the distance between the Chinese audience and the dubbed Soviet films as well as their Soviet characters, although assimilating cultural foreignness into Chinese culture was not without consideration for the "original flavour." To make the lines easy to understand for the Chinese, the propagandists from the Ministry of Culture commanded the filmmakers to avoid word-for-word translation of Russian idioms but to find a Chinese saying equivalent in meaning - they should use paraphrases instead of metaphrases. Here is a salient example: when translating the exclamation "0, мой бог (Oh, my god)," instead of the literal translation of "哦, 我的上帝 (o, wode shangdi, oh, my god)," which is unfamiliar to mainstream Chinese culture, translators used "天啊 (tian'a, Heaven)." The Ministry of Culture approved of the latter translation because while both "tian'a" and "0, мой бог" were "expressions of superstitious emotion," the "tian'a" translation would make the Chinese audience feel more familiar and thus "intimate" because it was Chinese slang (Committee of Art in Film Bureau of the Ministry of Culture 1950: 9). With the domesticating translation, dubbed Soviet films produced the image of the Soviets as easily understandable and more familiar to the Chinese audience.

The dubbing actors' vocal performance was also expected to be domesticating. During the 1950s, a crucial concern for dubbing artists was how to accurately represent the Soviet characters through their voices. Their performance had to "match" or synchronise with the original images in the Soviet films. Not only should the dubbing actors' voices match the lips of the Soviet characters, but the emotions in the voices should correspond to those of the characters. Interestingly, when the dubbing actors worried about whether they could adequately understand these foreign heroic figures' thoughts and emotions, they oftentimes looked to their own life experiences, observations of people in everyday life, and even stories and reports of Chinese heroes of the time. For example, when dubbing Dream of a Cossack (1951), actor Liu Qun 劉群 not only read books about Soviet farms, but also "stories about Chinese heroes," and "researched the psychological activities of a lot of our old peasants" (Bu 1954: 25). What transpired in Liu's vocal performance was a domestication of emotions of the foreign film characters. Articles describing such stories as Liu's were regularly published in propagandist film magazines, signifying an officially-approved way of dubbing (Zhang 1957: 117; Xinru 1954: 26). By imbuing the foreign characters with emotions developed from Chinese local experiences, the dubbing practices reduced the characters' foreignness and brought a familiarised image of the Soviet allies to the Chinese audience.

The Chinese propagandists' expectation of the dubbed Soviet films in many ways resonates with Abe Mark Nornes's theory on dubbing, which highlights domestication as "built into the standard conventions of dubbing" (Nornes 2007: 220). To Nornes, the medium of dubbing is fundamentally domesticating, since "the foreign language is completely extracted, replaced with sameness" (ibid.: 219). Furthermore, Nornes mentions the possible effect of dubbing in constructing transnational character identification, which is brought by the very phenomenon of "the foreigners speaking the target language." He quotes Harada Masato, the dialogue translator and director of Japanese dubbings of a series of American films, who claimed that when he watched his own dubbing in Full Metal Jacket (1987), he was "so moved" precisely because the character was speaking Japanese:

If it is subbed, the people on the screen are really foreign because they look different and speak a language you can't understand. There's a built-in distance. But with dubbing it's close. They are white, but when Cowboy dies at the end, it was like a friend died because he was speaking Japanese. I want Japanese to feel that kind of pain, but they won't if it's subtitled. It's simply not the same. (Nornes 2007: 220)

Harada's experience allows a way to imagine the connections between the audience and the dubbed characters: with the foreign characters speaking the target language, the audience might feel close to them. However, Nornes's theory, with its emphasis on domestication, might tell only one side of the story. Emotional intimacy is not the only possible audience reception; dubbing can also potentially cause resistance among the audience for the irreconcilable image-voice split. There are other critical theories of voice and dubbing in cinema that can provide useful tools to complicate our understanding of the experience of watching dubbed foreign films and help us better understand the role dubbing played in the dubbed Soviet films.

As argued by most scholars of Cinema Sound Studies, since the birth of the sound film, there has been a gap between the image and the voice. The screen does not talk - the voices spectators perceive are not from the visible mouths on the screen, but from the speaker of the sound system in the cinema. As Michel Chion comments, the physical nature of film necessarily "makes an incision or cut between the body and the voice" (Chion 1999: 125). The sound film thus is always dualistic, and is always trapped in the image-voice split. To overcome this split and make the spectators believe that the voice comes from the actor on the screen, or in other words, to achieve audiovisual realism, sound films must try to match the moving image with the voice. Rick Altman has famously compared the sound film to ventriloquism in that it conceals the true source of voice (the loudspeakers, usually behind the screen) and matches the lips and other bodily movements with the voice. In this way, sound film fosters "the pseudo-identification of the sound source" and restores the "naturalness" of the character on screen (Altman 1980: 77). Combining synchronism and synthesis, Michel Chion comes up with the notion of synchresis, the "weld" produced "between a particular auditory phenomenon and visual phenomenon when they occur at the same time" (Chion 1990: 63). Chion claims that this "weld" is spontaneous and irresistible, and he highlights it as the apparatus with which the sound film sutures the voice back to the body.

With the actors on screen speaking a foreign language, dubbing makes the image-voice split noticeable and tangible. This split, to Chion, can also be covered with synchresis, and he insists that it is possible for the audience to believe the character on the screen speak another language. However, it is important to note that synchresis in dubbed foreign films does not always or promptly succeed in naturalising the target-language-speaking foreigners. In his formulation of the image-voice relationship in dubbed films, Mikhail Yampolsky highlights the peculiar or alienating effect this image-voice gap creates. Reading Jorge Luis Borges' 1945 essay on dubbing, Yampolsky notices the moment when Borges compares dubbing to Chimera, the Greek hybrid monster composed of parts from multiple animals. Yampolsky describes dubbed films as creating a Chimera, because by showing an actor on the screen with a voice that he cannot make, these films combine different bodies together. He uses Jacques Lacan's concept of object a for his formulation of dubbing. To Lacan, voice is a kind of object $a$, which is something separable yet related to the subject. As object $a$ falls out and gets separated from the body, it leaves a lack, a void or cavity in the latter. Desire then originates from the cavity, circles around object $a$ and draws it back to the body, to store up the lack and restore its unity. Yampolsky shows that the dubbing voice, on the one hand, creates the illusion of being spoken by the body and belonging to the body; on the other, as an alien voice, distorted and foreign, it "loses the quality of object $a$ and does not create (...) a bodily hiatus" (Yampolsky 1993: 
76). Thus, the dubbing voice can never return to or regain unity with the body, and the Chimera is split and "riddled with cracks" (ibid.). This consequence creates a schizophonic effect, which, for Antonella Sisto, causes "psychic resistance in the filmic reception," and "alienation from the moving/sounding images" (Sisto 2014: 9). Yampolsky's theory allows us to see the possibility of a disconnect between image and dubbed voice and complicates the imagevoice relationship in dubbed films. If the phenomenon of "foreigners speaking the target language" to Abe Mark Nornes and Harata Masato enhances the audience's affinity for the foreign characters, Yampolsky's theory warns us this identification is never that easy.

The Chinese audience's reception also shows that the propagandists' plan for the dubbed Soviet films was not realised without challenges or difficulties. Watching foreigners speaking Chinese was a new experience to most Chinese audiences of the late 1940s and early 1950s. Articles explaining how the Soviets could speak Chinese appeared in film magazines from the first days of dubbed Soviet films in China. In his 1950 article "How can the Soviets speak Chinese," Chen Xuyi 陳叙—, leader of the Shanghai Studio, noticed that after watching dubbed Soviet films, many people felt surprised: "They say these are all Soviet films, but why do the foreigners all speak Beijing dialect?" (Chen 1950: 5). This is the moment when the Chinese spectators recognised the Chimerical body of the dubbed Soviet character, which became split and peculiar, and likely created resistance among the spectators rather than identification. It would be difficult to imagine the spectators feeling intimate with these distorted characters, not to mention being able to learn political lessons from them. This kind of article continued until 1954, suggesting that it took years to train the Chinese people to become the ideal audience for these dubbed films, and that at least in the early 1950s, the Chinese-speaking Soviets were viewed as a spectacle, a Chimera, to some audiences (Yao 1953: 296; Che 1954: 32). With the Soviet characters turning into a monstrous being, the CCP's expected reception of these films is likely to have been disrupted.

\section{Production of the strangers}

Because of this disruption, the effect of the domesticating strategy in translating and dubbing Soviet films can be questioned. Though the films were translated and dubbed under the central propagandists' expectation of producing familiar foreign friends, the Chinese-speaking Soviet characters nonetheless disrupted this perception. Further, as I show in this section, the translators and dubbing actors also showed their agency in the making of dubbed Soviet films. I highlight the foreignization practices and effects in the translation and dubbing process and show that domestication is never the only or even the most important characteristic of translated Soviet films. With the foreignization of translation and voice performance, the dubbed Soviet films also produced strangers - foreigners who were difficult to assimilate into Chinese culture, whose foreignness was preserved, and whose existence further disrupted the official imagination of the Sino-Soviet friendship.

On the level of dialogue translation, domesticating translation was never the only method for Chinese filmmakers. Although the propagandists in the central government promoted Sinicization in translation, they did not deny its limitations: Sinicization should be done only if it did not change the "original meaning" of the lines. Nor did they offer an absolute or hard-andfast rule of translation (Committee of Art in the Film Bureau of the Ministry of Culture 1950: 9). There was relative freedom for the translators to translate the dialogues according to their own imagination of how the foreign allies should sound in Chinese. Many of them claimed that the first and foremost principle of their translation was "loyalty to the original," and the first generation of filmmakers in the Shanghai Dubbing Studio were known for avoiding over-domesticating foreign films (Pan 2017: Kindle Location 551). As commented by Su Xiu 蘇秀, a dubbing actress since 1950 and a director for dubbed foreign films since 1954 in the Shanghai Studio, she made a special effort to avoid the use of Chinese proverbs in foreign films (ibid.). Sense-tosense translation never truly ruled the dubbed Soviet films, and with more foreignness in the dialogue preserved, the image of the foreigners became more complicated.

A good example of this is from Dream of a Cossack. When translating this film, the Changchun Studio encountered a Russian proverb "Своя рубашка ближе к телу" ("his shirt is closer to the body"), which signifies the character's concern for his own benefits and happiness. The translator Liu Chi 劉退 and dozens of his colleagues spent a great deal of time on this sentence. They tried old Chinese sayings such as "姐倆出門, 個人顧個人" (jielia chumen, geren gu geren, two sisters go out the door, each takes care of herself) and "兊死娘改嫁, 個人顧個人" (die si niang gaijia, geren gu geren, father dies and mother remarries, everyone only takes care of himself). But finally the filmmakers chose to use an almost word-for-word translation "自 己的䙉衫最貼身" (ziji de chenshan zui tieshen, his own shirt is the closest), which did not exist in Chinese and did not sound as local as the first two options. The translator himself wrote an article saying they were not sure whether this translation would be understandable to the Chinese audience: "I don't know whether the audience, after watching the film, could understand this sentence as we do" (Liu 1952: 19). At the risk of not being immediately understandable to the audience through literal translation, the filmmakers were able to preserve the foreignness in the dialogue and maintain the unfamiliar image of the foreigners to the audience.

In the dubbing process, the filmmakers also purposefully foreignized the Soviet characters. Since the first dubbed Soviet film Private Alexander Matrosov, an important method was changing the pronunciation of characters' names. The dubbing actors changed the tones, accents, and rhythms of the translated names to assert their foreignness. Take Alexander Matrosov as an example. Translated as 亞曆克山大馬特洛索夫, it is pronounced as "yà li kè shān dà mă tè luò suǒ fü" in Mandarin, with the characters separated from each other, with no accent, and with each character having its own tone. However, in the film, it is pronounced closer to the original Russian way, with a tone similar to the original and each character closer to each other. Another example is the name Stalin. In Chinese, it is pronounced "sĩ dà lin:" every syllable of this name is clearly separated, and each of the characters has its own tone. However, in dubbed Soviet films like Lenin in October, "si" and "lin" lost their own tone, and the name is pronounced with a rising tone on "da," which is similar to the original pronunciation. This method of pronouncing foreign characters' names in a way different from the Chinese suggested to the audience that these characters on the screen, although speaking the same language as the peasants and workers, were never really members of "us."

Therefore, by their active foreignization of the translated Soviet films, Chinese filmmakers called foreignness into the films and allowed the audience to view the Soviet characters as a foreign other. Further exploration of audience reception confirms the effect of these translating and dubbing practices. The first kind of audience response that challenges the propagandists' expectation of an image of the "intimate" and understandable foreigners involves misunderstanding. According to many reports, the Chinese audience constantly complained that they could hardly understand the theme of many Soviet film, that they felt it hard to follow the stories, and 
that sometimes they could not even tell one character from the other (Anon 1954: 36). ${ }^{5}$ What is of interest to this study is that often this problem of misunderstanding was related to the foreignizing practices of the translators and dubbing actors. On the level of translation, the literal translation seems to be hard to follow for the audience. A critic complained that the language was not "pure Chinese," and that many translated sentences did not sound grammatically correct, so "the audience could never understand the dialogue" (jiang 1954: 14). On the level of dubbing, the foreignizing way of pronouncing Soviet names also caused problems. "Even though the audience made great efforts [to follow the translation]," the critic claims, "they still could not understand it" (ibid:: 14-5). Failing to understand the characters or follow the stories, the audience might view the Soviets as ridiculous strangers and the dubbed films as nonsense.

Another kind of audience response came from those who valued the filmmakers' effort in foreignizing the films. A representative example is an article by Chen Danqing 陳丹青, who stated that the voice of the dubbing actors, especially the voice of Qiu Yuefeng 邱嶽峰, a famous actor at the Shanghai Studio, was purely foreign to the Chinese, "more foreign than the foreigners":

In China, the official discourse could not be delivered by him: can you imagine Qiu reading communist editorial articles, reporting news, telling the stories of model workers? The voices of the radio reporters were also top-class; they spoke with the force of justice, but you could only hear the stylised tones with absolutely no personality or temper. Qiu is a strange "alien," an Other to the national radio. He can only dub for the foreigners, outside the snares of China's public voices. We, the millions of listeners of the public radio, could not listen to any different tones if it was not from him: tender, elegant, sluggish, lingering, cunning, cynical, impertinent. He overcame the plot and the characters - yes, thinking about it now, what we greedily listened to and enthusiastically craved was the aura of the language and the voices: that is the human emotion and the human nature. (Chen 2003: 112)

The foreignness, according to Chen, was from the comparison between Qiu's voice and the highly stylised Chinese national voices, the voices of the radio reporters. Qiu and other dubbing actors or actresses' voices became "alien" and strange, because they did not fit into the stylised and overpoliticised soundscape of socialist China. With this alienated, defamiliarized voice, some of the Chinese audience acquired a way of imagining the foreigners and their foreign culture as something different from the Chinese people and culture and entrusted the other and the "there" with a meaning that they could not find "here." The foreigners were finally strangers; although speaking Chinese, they could not be understood as one of "us" by the Chinese people, and many Chinese watched and listened to them precisely because they were different.
In these films introduced to reinforce Sino-Soviet friendship, there were foreigners who were misunderstood, and foreigners who were alienated because of their incompatible difference with the Chinese soundscape. These audience responses point to the foreigners as strangers, and the transcultural practices of translating and dubbing foreign films allowed a space of freedom for the audience. They could imagine the world in a different way from the "friendship of the people," ponder possibilities other than the here and now, and even negotiate with or betray the revolutionary narrative.

\section{Conclusion}

As my investigation shows, what the dubbed Soviet films created was never a clear image of the "big brother." On the one hand, the official propagandists, promoting the Sino-Soviet alliance, expected the translators and the dubbing artists to produce an image of the Soviets as friends and comrades. On the other hand, these films also produced images of strangers who were different and incomprehensible. These different perceptions contributed to the ambiguous image of the Soviets in the Chinese audience's daily lives and disrupted ordinary people's imagination of Sino-Soviet friendship.

This ambiguity does not mean the CCP's project of winning hearts for the Soviet allies was a total failure, nor do I have any intention of denying the propagandist agenda's power over the minds of translators, dubbing actors, and spectators. The translators did use local sayings such as "tian'a" (Heaven) instead of "O, wode shangdi" (Oh, my god) in dialogues, and articles explaining why the Soviets spoke Chinese in these dubbed films disappeared after 1954 - several years of screening dubbed Soviet films seemed to have trained the Chinese people into the ideal audience for these films, an audience that did not feel surprised when foreigners spoke Chinese. What this paper tries to say is that while the official voices remained strong in the 1950s, the translators and dubbing actors still retained a certain agency in interpreting and representing the Soviets in an alternative way. And their works opened more possibilities for how the audience could imagine their Soviet older brother. With the dubbed voices, these films were never a simple instrument, but instead they complicated the way that people thought and felt about their foreign allies.

\section{Nan Hu is a doctoral candidate in the Department of East Asian Languages and Cultures at Washington University in St. Louis, USA. One Brookings Drive | St. Louis, MO 63130-4899, USA (nanhu@wustl.edu).}

\section{Manuscript received on 28 March 2019. Accepted on 13 December 2019.}

5. For more materials regarding the general issue of misunderstanding foreign films, see Du (2018); Liu Dishan (2015).

6. Translation is mine. Chen was born in 1953 and he claimed that he started watching foreign films at a very young age, and half of the movies he mentioned in his article were from late 1950s and early 1960s. Thus, his comments can be used to explore the reception of the foreign films around 1960.

\section{References}

ALTMAN, Rick. 1980. "Moving Lips: Cinema as Ventriloquism." Yale French Studies 60: 67-79.

Anon. 1954. “重視影片説明書的工作” (Zhongshi yingpian shuomingshu de gongzuo, We should pay more attention to the introduction of films). Dazhong Dianying 大衆電影 12: 36.
BERNSTEIN, Thomas P., and Hua-yu LI (eds.). 2009. China Learns from the Soviet Union, 1949-Present. Lanham: Lexington Books.

BU, Ping 卜平. 1954. “第一次會面” (Diyici huimian, The first meeting). Dazhong Dianying 大衆電影 3:24-5.

CHE, Xuan 車軒. 1954. “我們是怎樣進行配音工作的 - 配音演員 車軒給觀衆的回信” (Women shi zenyang jinxing peiyin gongzuo de? 
- peiyin yanyuan Che Xuan gei guanzhong de huixin, How do we dub? Dubbing actor Che Xuan's reply to the audience). Dazhong Dianying 大 衆電影 11: 32

CHEN, Danqing 陳丹青. 2003. “邱嶽峰” (Qiu Yuefeng). In 多餘的素 材 (Duoyu de sucai, Superfluous Material). Jinan: Shangdong Pictorial Publishing House. 110-4.

CHEN, Tina Mai. 2004. "Internationalism and Cultural Experience: Soviet Films and Popular Chinese Understandings of the Future in the 1950s." Cultural Critique 58: 82-114.

CHEN, Thomas. 2014. "An Italian Bicycle in the People's Republic: Minor Transnationalism and the Chinese Translation of Ladri di biciclette/Bicycle Thieves." Journal of Italian Cinema \& Media Studies 2(1): 91-107.

CHEN, Xuyi 陳叙一. 1950. “蘇聯人怎麼説中國話” (Sulianren zenme shuo zhongguohua, How does the Russian speak Chinese). Dazhong Dianying 大衆電影 $1: 5$.

CHENG, Jihua 程季華. 1957. “蘇聯電影早期在中國放映史實及其 他” (Sulian dianying zaoqi zai zhongguo fangying shishi ji qita, Facts and other topics about the early screenings of Soviet films in China). Zhongguo Dianying 中國電影 1:77-80.

CHION, Michel. 1990. Audio-Vision: Sound on Screen. Edited and translated by Claudia Gorbman. New York: Columbia University Press.

CHION, Michel. 1999. The Voice in Cinema. Translated by Claudia Gorbman. New York: Columbia University Press.

Committee of Art in the Film Bureau of the Ministry of Culture 中央 文化部電影局藝術委員會. 1950. “一九五零年翻譯片工作總結” (Yijiuwuling nian fanyipian gongzuo zongjie, The 1950 year-end review of translated films). Xindianying 新電影 11:9.

DU, Weijia. 2018. Exchanging faces: Dubbing foreign films in China, 19491994. Ph. D. Dissertation. University of Illinois at Urbana-Champaign.

HEINZIG, Dieter. 2004. The Soviet Union and Communist China, 19451950: The Arduous Road to the Alliance. Armonk, N.Y.: M. E. Sharpe.

HESS, Christian. 2007. "Big Brother is Watching: Local Sino-Soviet Relations and the Building of New Dalian." In Paul Pickowicz and Jeremy Brown (eds.), Dilemmas of Victory: The Early Years of the People's Republic of China. Cambridge: Harvard University Press. 160-83.

HUANG, Nicole. 2013. "Listening to Films: Politics of the Auditory in 1970s China." Journal of Chinese Cinemas 7(3): 187-206.

JIANG, Yi 壃缶. 1954. “對翻譯影片的幾點意見” (Dui fanyi yingpian de jidian yijian, Some opinions on translated films). Wenyibao 文藝報 5: 14 .

JIN, Haina. 2018. "Introduction: The translation and dissemination of Chinese cinemas." Journal of Chinese Cinemas 12(3): 197-202.

LI, Yan. 2018. China's Soviet Dream: Propaganda, Culture, and Popular Imagination. Abingdon, Oxon and New York: Routledge.

LIU, Chi 劉退. 1952. “金星英雄翻譯雜記” (Jinxing yingxiong fanyi zaji, Notes on the translation of Dream of a Cossack). Dazhong Dianying 大蕆 電影 $14:$ 18-9.

LIU, Chi 劉遲, and MENG Guangjun 孟廣鈞. 1952. “東北電影製片廠
的翻譯工作" (Dongbei dianying zhipianchang de fanyi gongzuo, The translation work of the Northeast Film Studio), Dazhong Dianying 大衆 電影 $14:$ 17-8.

LIU, Dishan 柳迪善. 2015. 新中國譯製片史 (Xinzhongguo yizhipian shi, History of translated films in the PRC). Beijing: China Film Press.

LUKIN, Alexander. 2003. The Bear Watches the Dragon: Russia's Perceptions of China and the Evolution of Russian-Chinese Relations Since the Eighteenth Century. Armonk, N.Y.: M. E. Sharpe.

LÜTHI, Lorenz M. 2008. The Sino-Soviet Split: Cold War in the Communist World. Princeton: Princeton University Press.

MENG, Guangjun 孟廣鈞. 2003. DWM-ORG-01-00446. 孟廣鈞采訪 01 (Meng Guangjun caifang 01, Interview of Meng Guangjun 01). Cui Yongyuan Center for Oral History at Communication University of China.

NORNES, Abe Mark. 2007. Cinema Babel: Translating Global Cinema. Minneapolis: University of Minnesota Press.

PAN, Zheng 潘爭. 2017. 棚內棚外: 上海電影譯製廠的輝煌與悲 愴 (Pengnei pengwai: Shanghai dianying yizhichang de huihuang yu beichuang, In and out of the dubbing studio: the splendor and sorrow of Shanghai Dubbing Studio). Beijing: Sanlian shudian.

RADCHENKO, Sergey. 2009. Two Suns in the Heavens: The Sino-Soviet Struggle for Supremacy, 1962-1967. Stanford: Stanford University Press.

SHI, Zhe 師哲. 2015. 在歷史巨人身邊 一師哲回憶錄 (Zai lishi juren shenbian - Shi Zhe huiyilu, Near the Great Man in History: Memoir of Shi Zhe). Beijing: Jiuzhou Publishing House.

SISTO, Antonella. 2014. Film Sound in Italy: Listening to the Screen. New York: Palgrave Macmillan.

VOLLAND, Nicolai. 2017. Socialist Cosmopolitanism: The Chinese Literary Universe, 1945-1965. New York: Columbia University Press.

WANG, Tingjun 王霆鈞. 2014. 長影的故事 (Changying de gushi, Stories of Changchun Film Studio). Beijing: Sanlian shudian.

WESTAD, Odd Arne (ed.). 1998. Brothers in Arms: the Rise and Fall of the Sino-Soviet Alliance, 1945-1963. Stanford: Stanford University Press.

XINRU 欣如。1954. “艱苦的, 創造性的勞動” (Jiankude, chuangzaoxingde laodong, The hard and creative work). Dazhong Dianying 大䒈電影 $3: 26$.

YAMPOLSKY, Mikhail. 1993. "Voice Devoured: Artaud and Borges on Dubbing." Translated by Larry P. Joseph. October 64: 57-77.

YAO, Junchu 姚俊初. 1953. “我們怎樣製作翻譯片” (Women zenyang zhizuo fanyipian, How do we make translated films). Kexue Dazhong 科 學大衆 8: 296.

YU, Miin-ling 余敏玲. 2015. 形塑新人: 中共宣傳與蘇聯經驗 (Xingsu xinren: zhonggong xuanchuan yu sulian jingyan, Shaping the new man: CCP propaganda and soviet experiences). Institute of Modern History, Academia Sinica, Taipei.

ZHANG, Yukun 張玉昆. 1957. “回憶配演馬特洛索夫的譯製工作” (Huiyi peiyan Mateluosuofu de yizhi gongzuo, My memory of dubbing Matrosov). Zhongguo Dianying 中國電影 11-12: 116-8. 